\title{
The Perception of a State of Insecurity in Literature on Global Occurrences. Gehen, Ging, Gegangen vs. Die Flucht
}

\author{
Miodrag M. VUKČEVIĆ10
}

${ }^{1}$ Assoc. Prof. Dr., University of Belgrade Faculty of Philology, Belgrade, Serbia

\section{Corresponding author: Miodrag M. VUKČEVIĆ, \\ University of Belgrade, Faculty of Philology, Studentski trg 3, 11000 Belgrade, Serbia \\ E-mail: mvukcevic@fil.bg.ac.rs}

Date of receipt: 03.09 .2018

Date of acceptance: 31.10 .2018

Citation: Vukčević, M. M. (2018). The perception of a state of Insecurity in literature on global occurrences. Gehen, Ging, Gegangen vs. Die Flucht. Alman Dili ve Edebiyatı Dergisi - Studien zur deutschen Sprache und Literatur, 40, 77-102. https://doi.org/10.26650/sdsl2018-0001

\begin{abstract}
ENGLISH)
The paper discusses two currently dominating global occurrences that appear to have common features. First, backed by the example of Jenny Erpenbeck's novel Gehen, Ging, Gegangen (2015) that addresses the migration flows we witness, questions will be raised about the differences in perception of the causes for global cultural changes seeking equalization and upholding, viewed from the perspective of Western civilization, and German particularly. In the second part of the paper Gerhard Gesemann's novel Die Flucht (1935), marking the anniversaries on the occasion of WWI, is being introduced in its function of a remembrance literature dealing with the retreat of the Serbian military in the Great War together with its expelled residents from the homeland to their asylum in Corfu. By comparing these two novels on both "refugee-ness" and state of insecurity, the paper points out different cultural forms existing because of the accumulated historical experiences, and shows how this circumstance influences the understanding of the aforementioned topics. Following this idea, the contribution underlines additional differences in defining the concept of home by describing cultural patterns and their treatment of the mediated reflected reality.
\end{abstract}

Keywords: German literature, hospitableness, refugee-ness, remembrance literature, state of insecurity 


\section{EXTENDED ABSTRACT}

Lately, two major topics dominated the picture of the media landscape. The first one, the topic of the refugee problem and the associated migration flows seem to have raised fundamental questions about intercultural conditions, especially in the integration discussion. In a global context, the discussions on the First World War and on the occasion of its anniversaries is the second main theme that sheds new light on the question of cultural boundaries, as viewed from Serbian historiography. The paper discusses these two currently dominating global occurrences that appear to have common features. First, backed by the example of Jenny Erpenbeck's novel Gehen, Ging, Gegangen (2015) that addresses the migration flows we witness, questions will be raised about the differences in perception of the causes for global cultural changes seeking equalization and upholding, viewed from the perspective of Western civilization, and German particularly. Referring to the way refugee subjectivity is perceived, it becomes very clear that the cultural pattern of the host community is determined by its historical experience. Such experience made by the German people is irrevocably marked by the division of the German state after the Second World War. In this case, a distinction can be made between a collective memory and the remembrance of individuals.

In the second part of the paper Gerhard Gesemann's novel Die Flucht (1935), marking the anniversaries on the occasion of WWI, is being introduced in its function of a remembrance literature dealing with the retreat of the Serbian military in the Great War together with its expelled residents from the homeland to their asylum in Corfu. Since the Middle Ages and culminating in WWI the historical experience of the Serbian people created a perception of statehood as an insecure category. In connection with this, the subject area of hospitableness gives a whole new dimension to the context of the migration flows and their cause. This will be examined in the context of cultural contact, especially motivated by the idea of the EU as a project of a common cultural space. Therefore, the question of disintegrative processes on what is today called the Western Balkans is considered to be important.

Relying on a culture founded in universality just the hospitality of Western Europe is questioned, accordingly. In addition, the migration flows towards Western European civilization reveal limits of contemporary cultural understanding. The reorganization of a cultural landscape after the First World War shifted the areas of tension to new ones as a result of the accompanying social changes. As is known, this can be seen in the reporting 
and media activity which began in the First World War and is becoming ever more intense. Regardless of the historical process during the Second World War, the beginnings of the documentary role of the media since the First World War seem to have reached the climax of their debatable function just today. But a literary-critical approach, including recourse to motifs from the history of literature, both in contrast to a reality staged by the media, provides insights into current processes of general cultural development.

By comparing these two novels on both "refugee-ness" and state of insecurity, the paper points out different cultural forms existing because of the accumulated historical experiences, and shows how this circumstance influences the understanding of the aforementioned topics. Following this idea, the contribution underlines additional differences in defining the concept of home by describing cultural patterns and their treatment of the mediated reflected reality. 


\section{Introduction}

No doubt, the starting point for today's analysis of problems regarding human society living in modern world is characterized by dynamism of changes resulting from progress, which influences life culture. Being put in a situation of precariousness, refugees found themselves exposed to the dichotomy between historical existence and current political aspirations. In connection with this, they appear to be a phenomenon that falls within a reference context in which the space is rendered relative by means of temporal categories. We still owe this to the scientific beginnings of half a century ago. The circumstance that the first century jubilee of the Great War is overtaken by the digital revolution reminds of the idea McLuhan (1968) had of the Gutenberg Galaxy leading to the Global village as well as the term "Globalization" used by Johan Galtung (1972) in his works dedicated to the rudiments of durable peace between states and people, but which is also devoted to the theory and practice of conflict resolution. While regionalism formed the backbone of the political agenda in the years these researches were originated, globalization was the movement that went opposite.

Today, at the time we are questioning the ideas which were adopted in various concepts of the modern society establishment, whether they were summarized under the term of a bourgeois society or a civil one, depending on the continuity we are favoring, historical or modern; we can also ascertain efforts to strengthen regional centers by emphasizing their own competitive advantages. In the following, this discourse shall contribute to the understanding of the perception of differences in creating an image of common civilization currents on two levels: the adaption of individuals to current social processes and by picturing global tendencies in their national cultural expression on the micro plan. This should be illustrated on the example of two literary works. First, the latest publication of the German novelist Jenny Erpenbeck entitled Gehen, Ging, Gegangen which deals with the current migration flows, refers to the way refugee subjectivity is perceived dependent on the cultural pattern of the host community. The second work, Gehard Gesemann's novel Die Flucht written on the topic of the Great War creates an image of a culture that struggles with its identity because of the location where it has developed its statehood. Situated on passage roads the culture has never experienced statehood as a stable category, but has come to know the state as insecurity. The retreat of the Serbian army accompanied by its people sheds light on the refugee subjectivity and understanding of the state in the sense of a historical category. 
Extending from the current public discourse and perhaps reaching back to the last 2025 years it is possible to realize three dominating major topics. The half a decade lasting anniversaries of the Great War are documenting the way international efforts handle with the results from solutions found in history for arising social tensions across borders. Such occurrences associated with the remembrance culture could be summarized to one of the complex themes, whereas the perception of the reality that is burdened by social conflict with the leading role of their reflection by the media is being additionally patronized in this second question cycle. Nevertheless, the second problem will not be addressed because of two reasons. First, the ambiguity in reflection and expression does not allow a clear assignment to one traditional line of development in history, and in connection with this, the space which is at our disposal is limited, of course. But the third item which arises on the daily agenda is considered to be asking for crucial questions today. Namely, the topic area of hospitableness gives a whole new dimension to the context of the migration flows and their cause. This is why this will be the starting point for the following research.

\section{1. "Refugee-ness" reflected in remembrance literature}

\subsection{German experiences}

In times when the understanding of history is obviously being characterized more and more often as an "era of commemoration"1, today we have laid the foundation for differentiating between collective memory and the remembrance of individuals. Assistance in perhaps connecting these two categories should offer a concept of remembrance created to represent a tradition of European culture. Next to the theme of WWI the current migration flows we are watching raise also questions of dealing with cultures in situations of cultural contact. Therefore, resulting from the worldwide refugee situation, the European culture of hospitality is questioned. To this end, latest discussions ask for the universality of a hospitality culture addressing Europe as an area with a culture founded in universality. But according to Kopriwitza (2016) this universality is being relativized by itself because the unconditional hospitality towards people from other cultures is possible only if the reception does not question the host culture "als solche (in ihrer Identität)" (p. 571) and therefore its universal character. Whether it is unexpected or

1 Investigating literature as a form of recollection Bodo Plachta noted in the beginning of the $21^{\text {st }}$ century that processes of contemplation of literature analogue to his approach appeared in France more than a decade earlier $(X)$. 
not, a solution for this quandary offers the culture itself. Current events, which are viewed from a perspective of a remembrance culture, a historical perspective of someone's own experiences, should give insights into regularities of general validity. Narrated from the perspective of a historically distinct social groundwork Erpenbeck's contribution to the results of the flow of traffic ending up in the so called Western civilization shows the limits of contemporary understanding of culture in a literary defined discussion framework.

The hot contender of the German Book Prize 2015, Jenny Erpenbeck's novel Gehen, Ging, Gegangen was praised in the public for hitting the nerve of time by putting ethical values of the Western civilization, viewed from German position, in relation to the worldwide migration phenomena that asks for regulations. In the secondary literature, the reception accordingly goes in the direction of the call for active political participation (Doliva, 2017). But not only singled out from the daily headlines, the leitmotiv of the dead at the bottom of the lake and his evoked dissolution appears symbolically for the dealing with the refugee situation in Western civilization. Moved into a lake, which borders on the garden of the protagonist, a retired university professor from the east of Germany, the masses of human beings who perish day by day in the Mediterranean locus a majore ad minus are to be brought closer personally to the readership. In view of the justifications for price lending, which are giving a clear signal for this politically committed work, the focus of the considerations is on the one hand dedicated to the consistent attention to the question of our time (Karbach, 2016, p. 9) but invites the reader on the other hand also to think about current topics without wagging their finger, rather to reflected entertainment than to world improvement (Karbach, 2016, p. 8).

Coincidently, the massive migrations flows from Middle East culminated right at the time the book was published. However, in Germany, the debate about migration flows right from the start obtained what Stefan Hermes (2016) called the "Aura des Dokumentarisch-Authentischen", an overrun of the "Grenze zur außerliterarischen Realität" (p. 181). In this regard, Stone (2017) gives a summarized overview of the development of the migration crisis and its transfer to Germany. Still in 2012, the suicide of an asylum seeker triggered protests that "served as a loaded space for social and political discussion and negotiation" (Landry, 2015, p. 399). The 550 days lasting protest of 100-150 asylum seekers at the Oranienplatz in Berlin (Stone, 2017, p. 2), on which Erpenbeck based her novel on, soon reached a political dimension by the mayor's involvement in the negotiations. Such a development, the moving of the refugees from public squares and places to accommodations in premises of public institutions (Bhimji, 
2016; Gehrke, 2017) first forms a context of a culture of civilized handling by pointing out an administrative procedure (Fadaee, 2015). But in the end that is certainly a result of cultural history.

Born in the East of divided Germany as the third generation of a writers' family neither the Arabic language and Arabic world nor cultural divisions were strange to Erpenbeck. One of the refugees in her novel, the Ghanaian Awad, describes his childhood from the memories of a dichotomous world while he stays at the home of his host. In a historical analogy, such divisions are not unknown to the emeritus professor. Ones divided along the borderline set by the cultural adaption to civilization progress (confrontation EastWest), the relation to reality is being transferred now to the dichotomy of existence. By creating an idea of death with this concept (Erpenbeck, 2015a, p. 77), though an eternity created in the described manner sets a gloomy prospect in perspective. As well as the migrants are gathered in an empty school building introducing themselves, the representative cultural function of the auditorium is being transformed into a mirror of the reach of cultural change processes: "Aus Niger. Aus Ghana. Aus Serbien. Aus Berlin. / From Niger. From Ghana. From Serbia. From Berlin. / De Niger. De Ghana. De Serbie. De Berlin" (Erpenbeck, 2015a, p. 37). Therefore, remembrance set up in context to reprocessing appears to be analogous to the relationship between confrontation and projection.

Berlin ultimately represented as a symbol of insecurity and escape is moved to its historical role. The circumstance that people, relatives, brothers and sisters once were prevented from walking by a wall; Rufu from Burkina Faso thinks that administrative efforts have solved this issue. Because of analogies in comparing the North African situation today with the history of Berlin, Richard, the retired German professor comes to the conclusion that the communication, according to Apel (2015), fails to answer questions on the relationship between the former parts of divided Germany (Wir wurden, werden, sind sichtbar, para. 2). Once, Berlin was a symbol for escape, indeed, a symbol of an escape from projected violence and again from the capitol of a state of insecurity. Being this kind of a symbol the German capital serves to remind us of this situation putting an icon for the projection of non-violence. Against that, the accommodation of asylum seekers and agencies for refugee assistant situated at the city borough that is worldwide know mostly because of its precarious position during the period Berlin was divided, and for the relatively large number of citizens of foreign origin, arouses the impression the authorities are setting up a restricted area. At the same time this is the outlook of society into the future. 
Examples of the human fight for dignity, whether by Luther's Theses or the protagonist's thoughts about the basic needs of human kind, flow into a forest of information the coverage by broadcasting services are not able to present in a real frame (Erpenbeck, 2015a, p. 28). The first reactions to the work we find in the press borrow for this purpose elements that point to the significance of own origin. "Fauxpas" picked out from the abundance of the described human suffering should possibly help to uncover the key issues of the novel (Knipphals, 2015). Whom should be explained to the own history? - Or should the question be who should be asked questions from whose history, from what 'story'? Hence, do these questions refer to historiographically guaranteed information or to data which will have to serve just for historiography? Alternatively, do we have stories about the destiny of individuals whose example stands symbolically for the self-perception in historical processes? The history of the relationship to foreign cultures and a cultural ideal are analogous to the relationship between, linguistically alluded in this case, France and Germany. Both, Germany's position in Europe as well as the history of its division are being provoked right by the cultural context arising in the current migration crisis. Balancing between cultural trends which create a European image based on a foreign language, "never brown in town" (Erpenbeck, 2015a, p. 43), and its historical experience force the German society to meet being a stranger - to recognize the stranger trait in itself in order to understand strangers - is the perspective of being a stranger (Knipphals, 2015). A cultural context is given by the cultural role model that puts the foot in it giving statements, but the true cultural carrier relativizes his constant effort in only one Faustian truth: "Und sehe da, dass wir nichts wissen können!" (Erpenbeck, 2015a, p. 37).

\subsection{Cultural foundation of Europe}

It is true that catchwords such as crusades and crusaders seem to be strange today. The recourse to the Middle Ages in the perception of Europe may perhaps describe the struggle for supremacy not only in the Holy Land, but also in the world, as it was known. However, with the Christian-occidental tradition, which is often cited in the European context, this does not have much in common. Although the concept of Erpenbeck's novel suggests relationships that advocate a certain cultural stature, an interpretation in this direction would miss the overall concept. The core question concerns the dealing with a cultural contact, which is characterized by massiveness and leads to the confrontation of cultural processes. Supported not least by globalization tendencies the search for a solution happens predominantly on European soil. 
More than significant is Jenny Erpenbeck's description of the European audience which observes the happenings. Despite the fact that the student fell asleep during the seminar, her work showed later on that she was capable of dealing with the questions emerging from the old philological topic Ovid. Understood as a description of the genesis of the world by the merged Greek and Roman mythology, Ovid is still in addition a source for research on questions related to the time perception of the past, present and future based on the relationship established according to the contents transferred over time. Ethically, the work on this inexhaustible material stands for values which are attributed to the now unified European cultural area. This is why it is possible to understand Ovid as a remedy against heartache (Erpenbeck, 2015a, p. 10). The protestant basic attitude towards work allows the combination of two different human needs: love and benefit. However, it has also a twofold character. Authenticated at the same time in repentance (Erpenbeck, 2015a, p. 27) the descent of Odysseus in the Hades gains a new significance. Faithfulness, which is understood additionally as another leitmotiv in Erpenbeck's novel, can only be overcome by means of a permanent readiness for work. Only in the immediate confrontation with the conflict situation are prospects for the conflict resolution available. In the context of different levels of meaning in Ovid's Metamorphoses, the Western society appears in its pseudo-identity as visible invisibility whereas the anonymity of the migrants seems to be an invisible visibility. The authority of the legal apparatus, Odysseus as the Cyclops' nobody, hides at least behind its own blindness (Erpenbeck, 2015a, p. 32).

In order to enable the understanding of the nature of migration phenomena, the foreign culture he is faced with, Richard the classicist, gives to the migrants ancient names or names known from medieval-courtly epics, from Gottfried von Strassburg's courtly romance Tristan which is a prime example of the proof of literary social criticism. By this procedure Keller and Hammelehle (2015) recognize the principle of Europeanization of these people because of Richard's incapability to remember African names (Gut gemeint wie die ganze Willkommenskultur, para. 3). The way Richard recalls to the tradition, even the oldest, originating from his own culture, he reduces it to ways of fate. Just by preserving the tradition, the space for reviving memories is opened. Actually it does not matter whether the values expressed in the courtly ethos along with the ideas of virtue are based on Ehrismann's ideas about a virtue system which was derived from ancient moral philosophies or Curtius' melting pot thesis of Germanic, church, ancient and Spanish-Arab elements. Regardless of the cultural affiliation none should be excluded to be part of the knightly virtues of constancy, loyalty, service and honor. By contrast, the recognition in a legal system depends on the principle of distinction. Awad from Ghana 
becomes Tristan, sorrow, but the war victims are treated according to Dublin II (Erpenbeck, $2015 a$, p. 84). Of course, each time the reader is faced with people who have lost most of what has been gained in life, the novel is received as a'relevant reading matter'. However, Buchzik (2015) states that the protagonist tends to create a perspective of a conservative lifeworld and puts the migrants seemingly in the same level as Goethe's Iphigenia it was in Tauris (Trifft ein Berliner Professor auf Flüchtlinge, para. 7). The only difference she is aware of is that emigration and escape do not match. But this can be attributed to the limited ability of journalistic perception. In literary discourse the ideal of humanity of the German Classic, regardless of the dispute whether the antiquity served for projecting ethical values or was historically abused, whether it was imitated or replaced, has, according to Leber's (2011) conclusion, its own reality different from the Ancient (p. 99). Neither the escape of Iphigenia in Euripides's tragedy is equivalent to emigration nor is Goethe's symbolic recirculation of relations to an ancient Hellenic model a possible solution for defining the relations on the Crimean peninsula, "mit der Seele suchend" (Erpenbeck, 2015a, p. 82).

\subsection{Perspectives of movement}

Viewed from the protagonist's life section, entering the stage of retirement, a hitherto unknown social situation, probably not financially but released from daily commitments creates also uncertainties for the future, moreover emphasized by the death of his wife. Summarized in the words, "Vergehen soll sie, aber auch nicht vergehen", Apel (2015) points to the idea of timing that is included in the title itself (p. 1). Furthermore, his quotation taken from Grimm's Dictionary in regard to the irregular forms of the verb "gehen" the migrants are learning, indicates a changing from the perception of time to that of space. The conjugation of this "nach Form und Gehalt überaus reich entwickeltes Wort" (Apel, 2015, p. 1) includes envisioning of space and time on the whole, so that the verb that denotes motion mirrors the destiny of "refugee-ness".

In his interviews with the migrants, Richard interconnects his experiences associatively with those of the migrants made on their way through Europe. The countries turn into cultural areas which are known to the moderator. He is more familiar with cultural terms than with geography for which reason he has problems to create an image of the migrant's life. For him it is rather irrelevant which country they belong to, the desert dunes' roam just as the migrants have to pass the water barriers. The ambiguity hidden in this comparison shows the sense moving gets only at its stations 
on the passage. In this context, Pokrywka (2017) interprets time as a metaphor in which the phrase "gehen, ging, gegangen" forms a framework for reflection on disturbed understanding of time. So the refugees are not caught "im Raum, sondern im Warten gefangen, im Raum ohne Zeit" (p. 415). Unifying the ideas of 'del deserto' and Toscana, Lampedusa as well as the Greek temple of Agrigento with the prospect from an airplane (Erpenbeck, 2015a, p. 66) strengthens the image of strangeness. This also is the nature of the desolate outlook which awaits the refugees and limits them in their freedom. In contradiction to the title Birrer (2015) determines the main topic between "Aufbrechen und Ankommen, Fliehen und Festsitzen" in the question "Wohin geht ein Mensch, wenn er nicht weiss, wo er hingehen soll?" (Gestrandet in der Warteschlaufe, para. 9). The description of the refugees initial situation, the situation of lost home, allows comprehending the aimlessness and lack of perspective that results in the loss of the own identity: "Man weiß nicht, wohin. Man weiß nichts mehr. Ich kann mich selbst nicht mehr sehen, das Kind, das ich war. Ich habe kein Bild mehr von mir" (Erpenbeck, 2015a, p. 80). Such a loss of self-reflection finally results in disorientation which has its expression in a movement spreading in all directions of heaven. As a matter of fact, this speaks about hopelessness and the way to uncertainty. The picture is displayed through the lost orientation without having anything in perspective, without an idea of where to find home, and left with nothing, no home left behind. All these issues set up the groundwork not only for establishing an existential being for refugees, but an experience of statehood as insecurity.

A confrontation of individuals with overlapping cultural circles seems to be not just an inescapable apparition but also quite a need for participation in social processes. Of course, the starting point for perception of cultural contacts is always the ambiance of the culture of origin. And for this purpose, cultural gradations have to be understood as a cross-border phenomenon which encloses different forms of cultural expression of the same origin. Not too long ago, very painful experiences were made in shading ascriptions to certain cultural circles in Europe. During the war on the Balkans the German-Slavic language border on the South got very coveted (Erpenbeck, 2015a, p. 85). Now the historical borders of the Western civilization's ancient origin are critical.

Because of the differences made between cultural circles in regard with the process of their development, the generally valid opinion today inclines to the supposition that, to this end, the civilization process is in causal relationship. How should we interpret then Richard's assertion that today Apollo has an internet-enabled mobile phone, too 
(Erpenbeck, 2015a, p. 69)? Hence, this raises the further question of whether even related cultures that have developed due to the adaptation to varying external influences each other apart, can find common ground again in times of crisis. Richard wonders if Norway and Sweden would issue passports to the Icelanders and employ them if a war breaks out between Alaska and Iceland so that the Icelanders could not return to their home (Erpenbeck, 2015a, p. 85). Therefore, the instability of cultural borders questions even a culture of solidarity.

In addition to the all-round progress of civilization determining culture, two of the most important characteristics for society in particular are the rise of material welfare as well as the administrative regulation ensuring social security. A decisive factor is undoubtedly the perception of reality strongly influenced by a behavior of consumerism. The retired professor, Erpenbeck's protagonist has difficulties in committing to memory people's names; he mixes them up with consumer's brands. But also he will handily fathom the social implications of the migrants' stay in their host countries. In Germany the first reactions on the novel quote descriptions of visits at public offices stating that the status of the migrants is defined by their commitment to leave. However, the young migrant understands his status, "wenn ich gehen muss, kann ich gehen", as a free man's one (Apel, 2015, para. 3). An interpretation from this point of view is comprehensible if the constitution of a guest is considered as a "scheinbar paradoxe privilegierte Ausgeschlossenheit aus der sheimischen< Gemeinschaft" (Kopriwitza, 2016, p. 565). In case that a refugee is excluded from his/her shomer community he/she is also free to join another community for a certain period and his commitment to leave is the future prospect of the opportunity he will have at joining in freedom again.

\subsection{The sense of alienation}

The high-contrast interplay of memories between refugee narratives and a remembrance culture derived from a German post-war fate, creates opposites which at least cancel each other out trying to establish a cultural communication. Osarobo, the piano player, whose parents were living separated in different parts of Africa, is an example of a destiny historically determined by social relations as well as Richard's friends in adapting to the new conditions after the historical turn of the German reunion. Similarities between Raschid's memories of his childhood in a large family and Richard's memories of his friend Walther, whose family life was and after his death is still marked with institutional visits to offices, may differ on the religious and the social 
backgrounds. They represent varieties of concepts defying home. Both, the common source of the ethical understanding enclosed in the emblem of the Virgin Mary giving birth to the child and the realization of ethical values defined by institutionalized social responsibility represent different cultural cluster. In her research article Stone (2017) puts an emphasis on the cultural differences resulting from the step of civilization reached by societies. Her description of institutionalized cooperation of European countries in migration matters and in particular the corresponding legal regime in Germany (Stone, 2017, p. 2-3) shows to what extent the progress of civilization also influences the understanding of culture. The paradox of misunderstanding in the process of adapting ethical values though institutions refers to the different expectations of the level of civilization. While the control of citizenship is supposed to protect the individual in society, the violation of the security of the individual just insists on his protection (Marciniak \& Tyler, 2013, p. 146). Wiedemann (2015) draws attention to the example of the female Sudanese activist Napuli Langa, on which Erpenbeck episodically falls back on (Erpenbeck, 2015a, p. 18-19).

In order to understand the difficulties in cultural communication the perspective of East Germany, in particular East Berlin, serves to explain the historical connection to culture describing the style of the former arrangement in social institutions. Berlin understood as a hopper that gathers hybrid cultural forms, combining associatively the Huguenots and the Russian heritage dressed up in the Prussian gown of administration (Erpenbeck, 2015a, p. 58) points unmistakable to a tradition of order. The experience that the migrants can make every day is them being confronted to life forms regulated by connection to the "ordnenden Strukturen eines geregelten Tagesablaufs" (Keller \& Hammelehle, 2015, Gut gemeint wie die ganze Willkommenskultur, para. 6). Thinking in corresponding forms and trying to reach in life a form naturally ordered in advance (Erpenbeck, 2015a, p. 24) is the foundation for the functioning of the social structures in society. The Ghanaian Awad had a regular job as a car mechanic in Libya, where he grew up and regarded as his homeland. He first arrived in one European country, then as a tourist in Germany where he is seeking for asylum, and is now entering a space of thinking in categories of social assignment, which Richard puts in context with the German standards DIN \& TÜV (Erpenbeck, 2015a, p. 148). The Fiktionsbescheinigung sets the migrants on a list for being granted the status of refugee, and reminds the professor in retirement of fiction - in Italy the migrants will have to wait for years to get an Illimitata issued. They are caught between Dublin II and being an Asylbetrüger. Magenau (2015) asks for the intention and thinks to hit the point. He qualifies the "bürokratische 
Geometrie" (Ein Stückchen Acker in Ghana, para. 7) as an emotionless warmed up meal that has to deal with poor asylum seekers. Unfortunately, neither the undoubtedly existing intertextual link is interpreted within the framework of a literary-critical approach nor the idea of a state being still a symbol for insecurity is recognized. However, an approach that would lean on literary criticism would not fail to see the two opposite principles of coping life set in contrast to each other. The thinking in categories of order and definitions is one of the possibilities for coping with the challenges of life and stands against the idea of following reactively self-regulating processes.

Whether part of the society they belong to since they were neither born nor excepted in a society they have established their existents, furthermore the migrants seem to appear in a "Ausnahmezustand", so Kopriwitza (2015, p. 565), a state of emergency in which they were not integrated in the host society. Because of their cultural otherness the migrants' role of a foreign body could alleviate farewell rituals in case the host society would not have created a cultural relationship based on the cultural and economic progress centuries before. Richard questions his childhood memories of a book from the pre-war period which educated the children to be aware of their own cultural progress based on the civilization level that was reached. But reminding the immediate post-war period in divided Germany this earliest memory confronted with the memories of the fall of the Berlin wall, the reception rituals told him again about the expectations since 1990 which he is able to project now to the migrants. Obviously, monuments of cultural history change their meaning as time goes by, too. After the fall, the Berlin wall grew into the symbol of a welcoming culture that integrates refugees in daily life (Keller \& Hammelehle, 2015, Gut gemeint wie die ganze Willkommenskultur, para. 7). Repeatedly, the migrants show even in the state of being a refugee a willingness to help. In fact, mutuality characterizes the relationship of hospitality. As Koriwitza calls the idea of hospitality, welcoming guests and offering them basic needs for life a symbolic "Rückzahlung",' repayment of a liability "in der man ursprünglich steht", this "symbolische[...] Danksagung" means a "Hommage" to the "eigene Endlichkeit, Zerbrechlichkeit und Vergänglichkeit" (Kopriwitza, 2015, p. 561-562).

Exclusiveness, "refugee-ness" and disorientation summarized in the feeling of strangeness grows to leitmotiv moreover with the strangeness of the East Germans in reunited Germany and the 'Fremdeln' with a new life section or the 'Entfremdung' in a relationship (Keller \& Hammelehle, 2015, Gut gemeint wie die ganze Willkommenskultur, para. 5). Above all, Jenny Erpenbeck is very well acquainted with the experience of 
strangeness. The dissolution experience of the home state made by the citizens of the GDR is often reflected in the technical literature as admission to an already known home. But does this point of view cover all possibly raised questions? Probably, it is possible to interpret Erbenbeck's work under the premise of a gender-defined topic which can be put in the context of "fluidity of social structures" (Jones, 2006, p. 119). But the adaption to social structures viewed from the perspective of throwing off certain ethical ideas misses most likely the context of an interpretation from a position brought in relation to the East part of Germany. While he is talking with his friends about grievances in parts of the world and the benefit some other parts are having because of these circumstances, Richard counts his country and himself to the parts of the world which are having profit. After Detlef has repeated, "Hier bei uns, in Deutschland", Richard is not sure about the point his friend refers to. He concludes: "Das Land, das Deutschland hieß, war schließlich bis vor einiger Zeit nur auf der andern Seite der Mauer" (Erpenbeck, 2015a, p. 182). The identification with social structures and the values they are representing depends seemingly on the willingness to accept the offered value structures. Nevertheless, an established misbalance to the ethical values represented by the ruling social institutions pictures also a loss of home and solitude.

The plot organized by familiarizing the migrants by person, shaping case reports contributes to the fact that the stories are mixed up and the reader loses track of all the figures and forgets what is experienced by whom. This is because the migrants do not gain a deeper individuality beyond their escape stories (Magenau, 2015, Ein Stückchen Acker in Ghana, para. 6). Although there is a great panorama of fright, the concrete political background in the respective home countries remains diffused. The didactic purpose, however, is clear: To give the anonymous crowd of refugees personal faces and stories in order to increase empathy in this way. Each of the contacts to a possibly different individual case causes, undeniably, repeated alienation. Yet, the unification of the cultural contact to a wholeness of unknown cultures encourages the protagonist to learn more about differences in the alien cultures. The preparedness to get to know better the foreign cultures allows him to lay bare a similarity between the understanding of boundaries among migrants and his concept of boundaries. Richard becomes aware of the permeability of borders at a moment he realizes that he does not know the size of the Sahara. He comes to the conclusion that the boundaries between the countries which border in the desert, and which do not concern the desert dwellers, were 'drawn' also by the Europeans (Erpenbeck, 2015a, p. 66). But this very similarity seems to become an insurmountable threshold, an obstacle. 


\subsection{The home concept in the host society}

The appearance of the migration flows which question the concept of being at home in the host society, addresses the experiences of this society with regard to the tragedy of loss of home. According to Ludewig (2017) Richard pictures a temporary role of a surrogate father for the African refugees. Against that, Birrer emphasizes that the "exemplarisch aufflackernde [...] Humanismus" in the novel is shown "in seiner ganzen Erbärmlichkeit" (Gestrandet in der Warteschlaufe, para. 7). She locates Erpenbeck's intentions in presenting the utilization of the tragedy of other people to the goal of clarifying one's own ambivalent existence. Richard projects and reflects his own destiny in remembrance on the former period of his divided country. When spying on oneself was on the agenda and took over a control function, this created a specific atmosphere which raised the question of conformity. After the dissolution of this system the opening of the Stasi files (Erpenbeck, 2015a, p. 160) paved the way to self-imputation and selfbetrayal based yet again on a system-compliant concept of society. Obviously, these historical experiences appeared to be the motivation for Erpenbeck in shaping the surrogate father role.

The allegorical disguising of the migrants' existence in two examples for organizing a community in a systematical way gives to the retired professor a supportive idea about the refugees' destiny. Richard remembers the invitation of a friend of his, an archaeologist, to visit excavations at the Alex, the square Alexanderplatz. Allegedly the people have built underground halls where they were supplying themselves and trading in the Middle Ages. An analogy provides for Richard the Polish medieval city Rzeszów, likewise, which had apparently subterranean paths the people retreated to in order to escape from war atrocities. The retreat to the underworld is being transformed antithetically to projected freedom (Erpenbeck, 2015a, p. 19-20). In fact, history seems to pervert itself in the cynical opposite. After the provisional quarters at the Alex were tore off a tunnel system dug by rats became visible, an apparent system that makes profit in hidden tracks (Erpenbeck, 2015a, p. 54). In fact these allegories represent the reality of war, the reality of confrontation with preserving life.

If we transfer the dichotomous relationship historically to relations within Germany, two representative squares, each for East and West, Alexanderplatz and Oranienplatz, recall ideas about the divided city as well as about a multicultural past. But while, on the one hand, the division of the people after the Second World War has marked the identity 
of the entire German 'Volk' in a cultural historical frame, its multicultural history, on the other hand, has been transcended by social-economic conditions. Nevertheless, both identity constructions bear recognition features which are historically constituted and supported identity preservation through time independent of the rule system. Neither the material welfare nor the planned economy was convincing enough to explain any particular characteristic of the German people altogether (Erpenbeck, 2015a, p. 119). However, isolated differences in the identity construction between East and West Germans seem to become known just in relationship to the refugees. The professor's cultural-historical pioneering role is questioned regardless of the merits he has earned, by the need for further research on the origins of the world's grievances. He places the demonstrating refugees from the Alex in etymological and historical conditions of the Oranienplatz, in order to distance himself from the loss of a or rather his country. The hint to the compromise, i.e. he would not really believe in God (Erpenbeck, 2015a, p. 127), gets connected to the contemporary historical framework which makes the path to cultural-historical relativization possible. Osarobo compensates the loss of his country, his home, the loss of himself in his desire to play piano. The Divine Providence receives its content, thus confirming faith as a form of meaning.

\section{Gerhard Gesemann's Die Flucht}

The coincidence of the migration, more accurately, refugee crisis with the first century anniversary of the Great War gives reason to search for interconnections between these two occurrences. Back then, as now, the "obsessive matter" of war guilt for WWI (Bell, 1992 , p. 106) occupies the history experts. But only after the Second World War the space for asking the right questions was opened. The division of Germany based on ideological orientation created a suitable terminology for outlining social relations. This circumstance allowed putting the reason for the outbreak of WWI in a new context. Terms like "bourgeois-conservative class, industrial and financial capital" (Mombauer, 2013, p. 112) which appeared in public discourse affirmed contestations of the revisionist views which were mainly represented in West Germany. As a matter of identity construction economic relations were defined by ideological arguments which led to taking a position regarding the war guilt not only related to WWI but also WWII. Though, in literature the historical legacy after WWII is considered to be divided into three successor states, Austria, the Federal Republic of Germany and the German Democratic Republic (Kattago, 2001, p. 5). But the historical role attributed to the national states formed after WWII do not necessarily coincide with the awareness of their members. By building a wall, East 
Germany protected itself from fascist West since they deemed not to be part of the German tradition and Austrian historians dissociated themselves from "deutschen Wesen" (Mombauer, 2013, p. 127). Neither the GDR nor Austria identified themselves with the history of the German Empire before.

First of all, this paper is not intended to be a discussion on questions of guilt and neither of outbreaks of war or of its consequences. Namely, the underlying approach of this work tries to find common ground between German and Serbian history, arising from the understanding of the immediate living environment. It is out of question that, talking about mightiness, for the most economical reasons have led to tensions across cultural boundaries. The area of the Balkans is well known for being historically often in a state of insecurity. Here the existence of a refugee was experienced and surly still is further on in very different ways. The memories on the various convoys of refugees have marked the Serbian experience in "refugee-ness". Known as a space of passageways and crossroads the concept of home be possible to compare with the procedure similar to the example Jenny Erpenbeck sets on her protagonist. Derived from Gesemann's approach, Reber (2008) interprets a Nietzschean influence in the reinterpretation of scientific terms "blood" and "race" (p. 5) which are placed in a cultural-scientific context.

The novel Die Flucht (1935), a diary written along with the literary and aesthetic tendencies current at the time of originating, can be read as a historiographical contribution by Gesemann, using examples of the transcription of oral tradition. Preserved verses of folk songs on Serbian about rivers rolling over grove and gravel, "Valja drvlje i kamenje" (p. 8), and the "'feurigen' Polizeimänner - ognjeni čauši -“" (p. 9) tells about a traditional conceptualization of the German perception. In the earlier German reports from the Balkans 'Tschausch' served for describing a mentality of thugs and ruffians. Such a perception, however, speaks rather of a stereotype, which is probably derived from the historical perception of the areas inhabited by this people. The author of the book, Gesemann, participated in the Great War in capacity of a medical assistant during the retreat of the Serbian army, the government and parts of the people via Albania to Corfu. He was faced with death and had to fight for his life. But like the retired professor Richard eight decades later will quote a Pommeranian adage reminding of the decisions of the Nazis in the last days before the surrender, not to leave their own people alive to the enemy, the ongoing professor at the German Charles-Ferdinand University in Prague, Gerhard Gesemann offered beforehand the example of being proud of making decisions in his own live regardless of the value of its existence. While an innate or 
educated resistance which is attributed to people, known as Serbian defiance, serves as a kind of protection of one's own being, an identity in which one recognizes oneself. The dedication to Jovan Cvijić, a Serbian geographer and ethnologist, given at the beginning, describes later on in a separate chapter named after him a kind of physiognomy of the experience, a knowing heart and a feeling mind (Gesemann, 1935, p. 119), which creates a cultural expression drawn in countenance.

\subsection{Cultural Boundaries and National Borders}

Not infrequently an epic tone of Albanian Calvary adheres to the columns of carts loaded with incapables to fight wars and with tailed cattle. Gesemann builds on the oral tradition, thereby to create a connection with the Serbian literary tradition, which is playing a historicizing function. The church Samodreža nearby Vučitrn on Kosovo reminds him on the eve of the Battle on Kosovo (Gesemann, 1935, p. 84). The mythological function of the fateful announcement is only strengthened while retreating again after the liberation of 1912. Myth formation appears rather as a historical learning process. The (mis)understanding of history in these areas may have contributed to what Ruthner, Cordileone, Reber and Detrez (2015) call "probably the most dramatic paradox" (p. 37) that revealed before the outbreak of war. Despite the "result of masterly diplomacy and sophisticated political engineering", the misjudgment of questions about existence, "the Austro-Hungarian occupation and ensuing annexation of Bosnia-Herzegovina only increased the South Slav danger it was meant to keep at bay" (Ruthner, Cordileone, Reber, \& Detrez, 2015, p. 37). Through a further differentiation in a cultural comparison, the rationalization can submit new conclusions from a priori established lines of argument or cultural lines.

Today, the EU project of a common cultural space anticipates cultural adjustment by cultural contact which is determined by the immediately surrounding and based "auf einer an die Geografie und ihre Kartografierung geknüpften Vernunft" (Reber, 2008, p. 6). The same idea was dictating the decisions of the Habsburg policy when their "military pointed out that taking over Bosnia-Herzegovina would [...] secure direct access to Serbia and Montenegro" (Ruthner et al., 2015, p. 25). Their assumption was based on the realization that the border is a spatial fact with sociological effects. In contrast, Georg Simmel (2006) argues in reverse. He interprets boundaries as sociological facts, which receive a spatial form. The idea that space is the imagination of ours, "[precisely]: daß er durch unsere synthetische Tätigkeit, durch die wir das Empfindungsmaterial formen, 
zustande kommt - “ is specified in the way that "die Raumgestaltung, die wir Grenze nennen, eine soziologische Funktion ist" (p. 304). Reinterpretation of conceptual relations facilitate, thoroughly, unifying a cultural space as a whole.

Starting from the common history in the area of the Balkans a cultural identity derived from folk literature and popular culture provides the creation of a "Serbian type" in a cultural context specific for the subject area. According to Ursula Reber this situation is the root position also for the "Montenegrin" (Reber, 2008, p. 6). The path leading from Kosovo further across Montenegro makes the retreat appear in an epic dimension. Gesemann calls to mind the old custom of division in tribes which was still current in Montenegro. Although the cross-generational efforts both since the Petrović dynasty and the rigidly guided state have tried to change the social structure, the old "partikularistische, oft anarchische Stammesgefühl" (Gesemann, 1935, p. 121) made the Montenegrin state sentiment be a mistrusted one. Consequently, freedom of decision-making is within a tradition in categorizing available.

Reber's (2008) discourse on Montenegrin's origin of name gives certainly a try to break away from the prosaic interpretations of earlier times, but stays, notwithstanding the will to develop a context of meaning derived from the natural landscape, because of the topographical terminology and the formation of links strictly inspired by borders further on in the political definition area. In addition to corresponding linguistic knowledge, cultural history is important in the same extent as the understanding of the origin of the attribute "black" for the 'Balkan' it is, whose designation is etymologically derived from Turkish, meaning black mountains and thus spatially territorial (Schwarz, 1888, p. 373). It is certainly an annoyance of time to foster more easily the old that existed before because of its age and chiefly because of the way of thinking connected to traditions, than to recapture the counterpart of reality to something detected as new. This is also the case with the attribute "black" which now serves as a supposedly distinctive feature mainly to shape radicalized stereotypes. Recent studies about the identity of the South Slavic people, dealing with political and economic dimensions of conflict consulting moreover ethnical aspects (Grabić, 2010, p. 10), claim to use the subject attribute in order to demonstrate the dimming of the Montenegrin culture by obtrusion of a historically evident groundwork (Grabić, 2010, p. 230).

In light of the refugees rows and migrations flows, the question of the functionality of borders is constantly being raised since drawing the national borders no cultural 
cornerstone seemed to be resistant enough against the pressure of changes. Merely the existence of nomadism might be an example for a continuous culture form existing across the borders. Its localization outside a territory, "[d]as Exterritorium" pictures the exterior of its qualities and imports them like this in a state (Reber, 2008, p. 10). To this end Erpenbeck (2015a) creates a parallel between ancient ideas about the Persian world and the retracing of the migrant's route: "vom Kaukasus über Anatolien und die Levante bis nach Ägypten und ins antike Libyen, [...] in den heutigen Niger und [...] wieder zurück ins heutige Libyen und über das Meer bis nach Rom und Berlin" (p. 178); in conclusion closing the circle of the 'Diaspora', the way faith and tradition were preserved supported by migration. She sees her novel as a confrontation of boundaries and move which strive for harmonization (Erpenbeck, 2015b, p. 3). In contrast, the trendsetting solution strategies offered by a 'civilizing mission' are also being projected onto the 'Exterritorium der Affekte' (Reber, 2008, p. 10). To that extent, the dichotomy of cultural and territorial identity generates social connections designed according to values derived from one's own historical experience.

Strictly speaking, it is the historical experience that has strongly provided diverse nuances of the interwoven structures in the Balkan area. These, obscure structures organized in clans, "undurchsichtige[...] Clanstruktur[...]en" consisting of agreements in "Geheimbündelei", which are captured in the term used by Reber (2008) who expounds in the term "Serbe" utilized also in documents of the Austrian-Hungarian military administration in Cetinje indicating an unattainable differentiation between the national declaration and the labors to establish a state (p. 11). Historically, the perception of loyalties is a matter of interests. Like contemporary relationships demonstrate, whether on a global plan or in regional frames, the marking of anniversaries of WWI like the Battle of Mojkovac show the relative character even of the historical perception. At times of the brigand tradition the protection and provision of the people was outside the established power structures (Gesemann, 1935, p. 14) and kept the tradition of the identity of the historical origin, the alliance between the Montenegrin and Serbian army ensured the independence of the ruling system for each.

\subsection{Culture - Identification - Human Being}

One of the reasons for the existence of refugees and migrants, the pursuit of interest which are not consistent with historical cultural structures is apparently a lack of willingness to share common cultural values. Different interests we can suppose just in 
the presence of separated phenomena of individuals or groups. An unambiguous sign for the general atmosphere of colliding interests in the early years of the twentieth century is set by the words of Austro-Hungarian foreign minister Andrássy, who adapted the principle "Macht geht über Recht" (Haselsteiner, 1996, p. 17). As a result, the attempt of the individual to maintain his own being in the war is finally expressed unswervingly. While he recalls images of a cultural contact in its most representative form, as it was the meeting of Stefan Nemanja and Frederick Barbarossa in Niš in light of the Third Crusade, Gesemann (1935) was overtaken by starvation (p. 23). The understanding of the individual is, of course, decisive as well as the reminiscences on Nikola Pašić (Gesemann, 1935, p. 22) show that it is not the political success or period of reign that characterizes him, but his understanding of war, the war that receives, yet loses the sense in sight of human existence.

Under the assumption that the answer on the meaning of the soldiers' moving in war may give a fair description of the reasons that cause an extending of movements, the question calls in fact for the irrational judgment that appears to succeed the circumstances and acquaintance. Subsequently, Kant's transcendental ideas may describe the irrational way of thinking at projecting a reality. According to Reed's (2014) reading of Kant, his "'der Hang in sich selbst gekehrt zu sein' [...] can make internally general notions seem to be external realities"' (p. 147). A reversal of this is possible if "der Mensch in die äußere Welt und dadurch in die Ordnung der Dinge, die den äußeren Sinnen vorliegen, zurückgeführt wird" (Reed, 2014, p. 147). This seems to fit the destiny of Serbian poets as the announcement and generalization of individual destinies to mass fate. Yet another question arises. Namely, to what extent participation in a national identity determines selfidentity. In current discussions as it is between Badiou and Žižek (2012) Kant's idea is retraced in the following terms: "dass wir als Intellektuelle die Position des singulären Universellen einnehmen sollten; also einer Singularität, die an der Universalität unmittelbar teilhat [...]. Man kann unmittelbar Mensch sein, ohne erst noch Deutscher, Franzose, Engländer et cetera zu sein" (p. 69). The placards put up by the demonstrating migrants in Erpenbeck's novel (2015a) evoke the same ascertainment: "Wir werden sichtbar" (p. 23).

Two different principles in the cultural development condition necessarily the emergence of various forms of social structures. The German culture which emerged in Central Europe adapted its cultural characteristics to a historical paragon of ancient civilization. In contrast, the cultures in the Balkans fought against alien cultural influence to preserve a historical heritage. Gesemann (1935) recognizes the remnants of Diocletia on 
the river mouth of Zeta and Morača walled in the castle of Podgorica (p. 131). While Goethe's "Asyl" discovered in Rome (Reed, 2014, p. 141) enabled subsequently a discussion on ethical and esthetical matters of culture, the Latin heritage in the Balkans, latent perspective of common civilization progress, went through a functional reorientation by the Ottomans. Next to the inherited infrastructure more significant are the social implications. Indeed, in Goethe hymning nakedness: "Uns ergötzen die Freuden des echten, nackten Amors" (Reed, 2014, p. 141), the authority of ancient forthrightness speaks about freedom. Nevertheless, in the encounter of a barefoot shepherdess, it appears for the migrants who recite out of Homer that the woman can claim neither the yarn nor the strings she weaves (Gesemann, 1935, p. 136). Historical experience determines therefore even the role and position of a woman in the society. Representing home she appears as a harbinger, which Reed (2014) cites with Goethe's thought "der unbehauste Mensch" (p. 138) and which became a cliché of the day for modern man's rootless, directionless existence, a view probably still widely ascribed to. Also, fallen back to the cave as a metaphor for life in the "Wald und Höhle" scene of Goethe's Faust (1808), the forest turns out to be the symbolic answer on the existence of human beings in the universe. Still at the beginning of his diary, Gesemann (1935) describes his impressions of the nature play, which, in his announcement of its unpredictability, contains the stimuli of human longing. His future perspective, "Jenseits beginnt die Wildnis" (p. 7), summarizes the existence as cultivated. Derived from $18^{\text {th }}$ century and edged in today's terms, the solution Reed (2014) offers to, has further on its daily topicality. Yet Kant asked "why European Man built grand palaces that an earthquake would destroy" when "[p]eople built more simply and safely in Peru, with a low stone base and the rest just reeds" (Reed, 2014, p. 143). In terms of cultural history the "earthly possibilities" and "the fundamentals of the human condition" (Reed, 2014, p. 138) ensured a development embodied in the appearance of Goethe's life as a symbol for circumstances allowing cultural uprising and development.

Finally, it can be stated that irrespective of the area where migration flows take place, the accompanying culture hikes are more a consequence of a reaction to the offered environment than a desire for cultural adaptation to civilization progress. Interpreting the way Goethe understands human nature as a bringing together sensory experiences mankind is, according to Reed, not just a subject that interposes in nature. The partnership built between nature and man (Reed, 2014, p. 140) evokes the cycle of answer and recurrence, a reactive relationship to environment. Seen from historical experience, the change in the theoretical discourse of cultural-philosophic content back to redefined economics is possibly a solution strategy that could be consulted for today's problems. 


\section{References}

Apel, F. (2015, September 16). Wir wurden, werden, sind sichtbar. Frankfurter Allgemeine Zeitung. Retrieved from http:// www.faz.net/aktuell/feuilleton/buecher/rezensionen/belletristik/gehen-ging-gegangen-von-jennyerpenbeck-13770081-p3.html

Badiou, A., \& Žižek, S. (2012). Philosophie und Aktualität. Ein Streitgespräch. Wien, DE: Passagen Verlag.

Bell, Ph. (1992). Themes in modern European history 1890-1945. In P. Hayes (Ed.), Origins of the War of 1914 (pp. 106-128). London, UK and New York, NY: Routledge.

Bhimji, F. (2016). Visibilities and the politics of space: Refugee activism in Berlin. Journal of Immigrant and Refugee Studies, 14(4), 432-450.

Birrer, S. (2015). Gestrandet in der Warteschlaufe. Neue Züricher Zeitung. Retrieved from http://www.nzz.ch/ feuilleton/buecher/gestrandet-in-der-warteschlaufe-1.18627304

Borchmeyer, D. (1998). Weimarer Klassik. Portrait einer Epoche (2nd ed.). Weinheim, DE: Beltz-Athenäum.

Buchzik, D. (2015). Trifft ein Berliner Professor auf Flüchtlinge. Der Spiegel. Retrieved from http://www.spiegel. de/kultur/literatur/gehen-ging-gegangen-von-jenny-erpenbeck-rezension-a-1050518.html

Curtius, E. R. (1948). Europäische Literatur und lateinisches Mittelalter. Bern und München, DE: Francke Verlag.

Doliva, L. (2017). Grenzerfahrungen in Jenny Erpenbecks Roman Gehen, ging, gegangen. In C. Schlicht \& C. Steltz (Eds.), Narrative der Entgrenzung und Angst. Das globalisierte Subjekt im Spiegel der Medien (pp. 171-191). Duisburg, DE: Universitätsverlag Rhein-Ruhr.

Ehrismann, G. (1970). Die Grundlagen des ritterlichen Tugendsystems. In G. Eifler (Ed.), Ritterliches Tugendsystem (pp.1-84). Darmstadt, DE: Wissenschaftliche Buchgesellschaft.

Erpenbeck, J. (2015a). Gehen, ging, gegangen (4th ed.). München, DE: Albrecht Knaus Verlag.

Erpenbeck, J. (2015b, November 2). Interview by ljoma Mangold. Gegen die herrschende Klasse. Die Zeit. Retrieved from http://www.zeit.de/2015/41/literatur-politik-gesellschaft-ilija-trojanow.

Fadaee, S. (2015). The immigrant rights struggle, and the paradoxes of radical activism in Europe. Social Movement Studies: Journal of Social, Cultural and Political Protest, 14, 733-739.

Galtung, J. (1972) Modelle zum Frieden. Methoden und Ziel der Friedensforschung. Wuppertal, DE: Jugenddienst.

Gehrke, C. (2017, May 22). Gerhart-Hauptmann-Schule: Das kostet das Flüchtlingshaus wirklich. Berliner Kurier. Retrieved from https://www.berliner-kurier.de/berlin/kiez---stadt/gerhart-hauptmann-schule-das-kostetdas-fluechtlingshaus-wirklich-26942822

Gesemann, G. (1935). Die Flucht. Aus einem serbischen Tagebuch 1915 und 1916. München: Albert Langen und Georg Müller.

Goethe, J. W. V. (1808). Faust. - Eine Tragödie. Tübingen, DE: Cotta'sche Verlagsbuchhandlung,

Grabić, D. (2010). Montenegrizität. Sprache und Kirche im Spiegel des Identitätsdiskurses in der Republik Montenegro, 1990-2007. In C. Hann, D. Schorkowitz \& S. Troebst (Eds.), Gesellschaften und Staaten im Epochenwandel 18 Frankfurt am Main, DE: Peter Lang. 
Haselsteiner, H. (1996). Zur Haltung der Donaumonarchie in der orientalischen Frage. In H. Haselsteiner (Ed.), Bosnien-Hercegovina. Orientkrise und Südslavische Frage (pp. 15-30). Wien, AT: Böhlau.

Hermes, S. (2016). Grenzen der Repräsentation. Zur Inszenierung afrikanisch-europäischer Begegnungen in Jenny Erpenbecks Roman Gehen, ging, gegangen. Acta Germanica. Jahrbuch des Germanistenverbandes im Südlichen Afrika, 44, 179-191.

Jones, K. (2006). “Ganz gewöhnlicher Ekel”? Disgust and body motifs in Jenny Erpenbeck's Geschichte vom alten Kind. In H. Bartel \& E. Boa (Eds.), Pushing at Boundaries: Approaches to contemporary German women writers from Karen Duve to Jenny Erpenbeck (pp. 119-133). Amsterdam, NL: Rodopi.

Kattago, S. (2001). Ambiguous memory: The Nazi past and German national identity. Westport, NY: Praeger.

Karbach, T. (2016, March). Berliner Autorin Jenny Erpenbeck bekommt Walter-Hasenclever-Preis." Aachener Zeitung. Retrieved from http://www.aachener-zeitung.de/news/kultur/berliner-autorin-jenny-erpenbeckbekommt-walter-hasenclever-preis-1.1306542\#plx2011429100

Kraljačić, T. (1987). Kalajev režim u Bosni i Hercegovini, 1882-1903. Sarajevo: Veselin Masleša.

Keller, M. \& Hammelehle, S. (2015 September 28). Gut gemeint wie die ganze Willkommenskultur. Spiegel Online. Retrieved from http://www.spiegel.de/kultur/literatur/bestseller-gehen-ging-gegangen-von-jennyerpenbeck-a-1055049.html

Knipphals, D. (2015, October 10). Fremde sind wir uns selbst. taz.archiv. Retrieved from http:// www.taz. de/!5238201/

Kopriwitza, T. D. (2016). Zur Phänomenologie der Gastlichkeit oder über die Pflicht Europas, gastfreundlich zu sein. In B. Liebsch, M. Staudigl \& P. Stoellger (Eds.), Perspektiven europäischer Gastlichkeit. Geschichte Kulturelle Praktiken - Kritik (pp. 561-578). Weilerswist, DE: Velbrück Wissenschaft.

Landry, O. (2015). "Wir sind alle Oranienplatz"! Space for refugees and social justice in Berlin. A Journal of Germanic Studies, 51, 398-413.

Leber, M. (2011). Goethes Iphigenie und die griechische Tragödie. In R. Bogner \& M. Leber (Eds.), Tragödie. Die bleibende Herausforderung (pp. 99-124). Saarbrücken, DE: Universitätsverlag des Saarlandes.

Ludewig, A. (2017). Jenny Erpenbecks Roman Gehen, Ging, Gegangen (2015). Eine zeitlose Odyssee und eine zeitspezifische unerhörte Begebenheit. In Th. Hardtke, J. Kleine \& Ch. Payne (Eds.), Niemandsbuchten und Schutzbefohlene. Flucht-Räume und Flüchtlingsfiguren in der deutschsprachigen Gegenwartsliteratur. Göttingen, DE: V\&R Unipress.

Magenau, J. (2015, August 30). Ein Stückchen Acker in Ghana. Süddeutsche Zeitung. Retrieved from https://www. sueddeutsche.de/kultur/longlist-zum-deutschen-buchpreis-ein-stueckchen-acker-in-ghana-1.2627330

Marciniak, K., \& Tyler, I. (2013). Immigrant protest: An introduction. Citizenship Studies, 17, 143-156.

McLuhan, M. (1968). War and peace in the global village. Bantam, NY: Gingko Press.

Mombauer, A. (2013). Uzroci Prvog svetskog rata (K. Todorović, Trans.). Beograd: Clio.

Plachta, B. (Ed.). (2004). Literatur als Erinnerung. Wilfried Woesler zum 65. Geburtstag. Tübingen, DE: Max Niemeyer Verlag. 
Pokrywka, R. (2017). Drei Metaphern des Exils im neuesten deutschsprachigen Roman: Gehen, ging, gegangen von Jenny Erpenbeck, Ohrfeige von Abbas Khider, Das Mädchen mit dem Fingerhut von Michael KöhImeier. Tematy i Konteksty. Pogranicza jako przestrzenie... konfliktów: zło konieczne? 7(12), 412-425.

Reber, U. (2008, September 23). ExTerritorium: Kartierungen und räumliche Formationen. Outlining Montenegro. Kakaninen revisited. Retrieved from http://www.kakanien-revisited.at/beitr/fallstudie/UReber5/?page=14

Reed, T. J. (2014). Der behauste Mensch: On being at home in the universe. Goethe, Kant, and others. Publications of the English Goethe Society, 83(3), 137-148.

Ruthner, C., Cordileone, D. R., Reber, U., \& Detrez, R. (2015). WechselWirkungen: The social, political and cultural impact of Austro-Hungarian occupation on Bosnia-Hercegovina, 1878-1918. Frankfurt, DE: Peter Lang.

Schwarz, B. (1888). Montenegro. Schilderung einer Reise durch das Innere nebst Entwurf einer Geographie des Landes. Mit III. nach eigenen Aufnahmen und einer Karte (2nd ed.). Leipzig, DE: Eduard Baldamus.

Simmel, G. (2006). Über räumliche Projektion sozialer Formen. In J. Dünne, S. Günzel, H. Doetsch \& R. Lüdeke (Eds.), Raumtheorie - Grundlagentexte aus Philosophie und Kulturwissenschaften (pp. 304-316). Berlin, Frankfurt, DE: Suhrkamp.

Stone, B. (2017). Trauma, postmemory, and empathy: The migrant crisis and the German past in Jenny Erpenbeck's Gehen, Ging, Gegangen [Go, went, gone]. Humanities, 6(4), 1-12.

Wiedemann, C. (2015, April 22). Berliner Flüchtlingsproteste. Was wurde aus den Aktivisten vom Oranienplatz? Spiegel Online. Retrieved from http:// http://www.spiegel.de/panorama/gesellschaft/berlin-was-wurde-ausder-frau-im-baum-a-1029106.html 